\title{
DETERMINATION OF SOUND TRANSMISSION LOSS IN LIGHTWEIGHT CONCRETE WALLS AND MODELING ARTIFICIAL NEURAL NETWORK
}

\author{
${ }^{1}$ Mustafa TOSUN, ${ }^{2}$ Kevser DINCER \\ ${ }^{1}$ Department of Architecture, Faculty of Architecture, Selcuk University, 42031 Selcuklu, Konya, Turkey \\ 2Department of Mechanical Engineering, Faculty of Engineering, Selcuk University, 42031 Selcuklu, Konya, \\ Turkey \\ ${ }^{1}$ mutosun@selcuk.edu.tr., ${ }^{2}$ kdincer@selcuk.edu.tr
}

(Geliş/Received: 24.10.2017; Kabul/Accepted in Revised Form: 24.12.2017)

\begin{abstract}
In this paper, analysis of sound transmission losses through lightweight concrete walls was conducted against the high way trafic noises. The walls are generally used for thermal insulation purposes in Turkey. Sound transmission was modeled using ANN. Input parameters frequency, density of lightweight concrete wall and thickness of lightweight concrete wall structure $\left(f, M, d_{2}\right.$ ) and output parameter TS were described.

When the outcomes of the TS analysis and those of ANN modeling are summarized together; Sound transmission losses improve with higher frequencies, higher wall densities and increased wall cross sections. Regardless of sufficient thermal insulation of single layered lightweight concrete walls as stipulated by the Turkey Institute of Standards (TSE 825), the wall cross sections were found to be insufficient in terms of sound transmission. Beside thermal insulation of the single layered lightweight concrete walls' regulations, it was found with this study that, it is also necessary to analyze sound transmission lossess, after which the wall cross sections should be sized.
\end{abstract}

Key Words: Artificial neuron network (ANN), Lightweight concrete wall, Sound transmit loss

\section{Hafif Beton Duvarlarda Ses İletim Kaybının Belirlenmesi ve Yapay Sinir Ağının Modellenmesi}

ÖZ: Bu makalede, ana yolu trafik gürültüsüne karşı hafif beton duvarlardan ses iletim kayıplarının analizi yapılmıştır. Duvarlar genellikle Türkiye'de ısı yalıtım amacıyla kullanılmaktadır. Ses iletimi ANN kullanılarak modellenmiştir. Giriş parametreleri frekans, hafif beton duvarın yoğunluğu ve hafif beton duvar yapısının kalınlığı (f, $\mathrm{M}, \quad \mathrm{d} 2)$ ve çıkış parametresi TS tanımlanmıştır. TS analizinin sonuçları ve modelleme sonuçları birlikte özetlendiğinde; ses iletimi kayıpları daha yüksek frekanslar, daha yüksek duvar yoğunlukları ve artan duvar kesitleri ile gelişir. Türkiye standart Enstitüsü (TSE 825) tarafından öngörülen tek katmanlı hafif beton duvarların yeterli 1Sı yalıtımına bakılmaksızın, duvar kesitlerinin ses iletimi açısından yetersiz olduğu bulunmuştur. Tek katmanlı hafif beton duvarların düzenlemelerinin ısı yalıtımının yanı sıra, bu çalışmada, ses iletimi kayıplarını analiz etmek için de gerekli olduğu ve daha sonra duvar kesitlerinin boyutlandırılması gerektiği bulunmuştur.

Anahtar Kelimeler: Yapay sinir ă̆̆, Hafif beton duvar, Ses iletim kaybı

\begin{tabular}{ll}
\multicolumn{2}{l}{ Nomenclature } \\
$\mathrm{d}$ & thickness of lightweight concrete wall, $\mathrm{m}$ \\
$\mathrm{f}$ & frequency, $\mathrm{Hz}$ \\
$\mathrm{Lm}$ & suggested noise criteria in various indoor areas, $\mathrm{dB}$ \\
$\mathrm{Lo}$ & main artery noise level, $\mathrm{dB}$ \\
$\mathrm{M}$ & density of lightweight concrete wall, $\mathrm{kg} \mathrm{m}^{-3}$
\end{tabular}




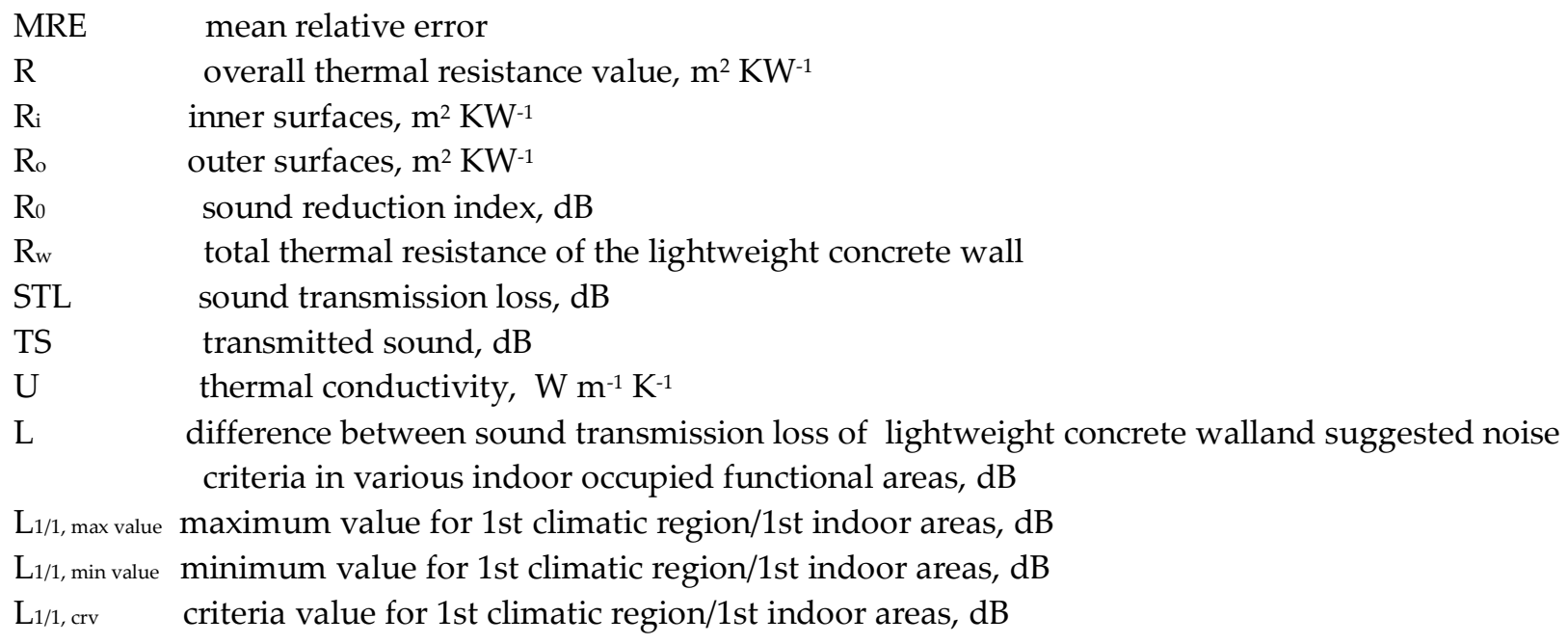

\section{INTRODUCTION}

There are various methods for predicting sound transmission loss of walls and floors that can be used by noise control engineers. It is important to know how accurate these methods are for typical constructions used in building acoustics. Results are presented for a number of different constructions showing how accurately the results of predictions match experimental laboratory results. The results will show the accuracy over the frequency range of 50 to 5,000 Hz. Both single and double partitions will be discussed. (Ballagh, 2004). There have been many studies on sound transmission loss in walls. Some are briefly mentioned below. Vigran (2009) conducted a study on prediction of sound reduction index of finite size specimen by a simplified spatial windowing technique. Legault and Atalla presented numerical and experimental investigation of the effect of structural links on the sound transmission of a lightweight double panel structure. Wang et al., (2005) examined sound transmission through lightweight double-leaf partitions by using a theoretical modelling. They noted that theoretical modelling of the sound transmission loss through double-leaf lightweight partitions stiffened with periodically placed studs. The models are used to explain the effects of incidence angle and of various system parameters. The predictions are compared with the existing test data for steel plates with wooden stiffeners, and good agreement is obtained.

Double drywalls composed of plasterboards have excellent characteristics such as light weight, easy installation, fire resistance and high sound insulation performance, and are often used for separating walls in apartment houses, hotels and office buildings. Recently, the requirement for sound insulation of building walls has become more strict according to the change in lifestyle and the standard of living. In addition, drywall construction is often applied to recording studios and cinema-complex buildings. In such cases, an extremely high sound insulation performance is required (Matsumoto et al., 2006). Active noise control technology has been used to increase the sound transmission loss of double-wall structures. Several approaches have been put forward and explored individually. However, no comparative study on those approaches has been conducted to show which approach is more effective for given circumstances (Bao and Pan, 1997). There are a variety of noise sources within the indoor noise environment of residential buildings. In particular, multi-storey buildings or neighboring apartment units which share wall, ceiling and floor structures provide structure-borne sound paths for the propagation of floor impact, airborne, and drainage noises (Jeona et al., 2010). The action of courtyard houses in reducing the noise nuisance from road traffic is examined using the techniques of computer simulation and acoustic scale modelling. This building form is found to be capable of reducing the noise level experienced within a protected space (indoor or outdoor) by a significant amount. For a courtyard house a fixed distance from a roadway, the most significant parameter, is found to be the height of the courtyard walls (Oldhama and Mohsen, 2003) . 
ANNs are good for some tasks while lacking in some others. Specifically, they are good for tasks involving incomplete data sets, fuzzy or incomplete information, and for highly complex and ill-defined problems, where humans usually decide on an intuitional basis. They can learn from examples, and are able to deal with non-linear problems. Furthermore, they exhibit robustness and fault tolerance. The tasks that ANNs cannot handle effectively are those requiring high accuracy and precision as in logic and arithmetic. ANNs have been applied successfully in a number of application areas (Kalogirou, 2003). An artificial neural network is a model of a biological neural network. The fundamental processing element of a neural network is a neuron, while the weighted connection is served as the synapse. The neuron receives inputs through the weighted connections, combines them in some way, performs generally a nonlinear operation on the result and then outputs the final result. ANNs have large numbers of neurons connected in a massive paralel structure (Zhang, 2005). ANN methods are applied in thermal energy practices, and also in different sub-disciplines of engineering science such as modeling of a thermal insulation system based on the coldest temperature conditions, (Tosun and Dincer, 2011), modeling fuel consumption in wheat production (Safa and Samarasinghe, 2013), analysis of total energy efficiency and optimization in an industrial sector (Olanrewaju et al., 2012), modeling of heating and cooling performance of counter flow type vortex tube by (Kocabas et al., 2010), and in air cooled heat exchangers (Kumar et al., 2006).

In this study, analysis of sound transmission loss through the lightweight concrete walls was made against highway trafic noises and then modeled with ANN. These walls are generally used for thermal insulation in Turkey. The results of the analysis conducted on 11 different background noises in various indoor occupied functional activity areas show that, on 4 different climatic regions in Turkey, the sound transmit loss on climatic regions with small cross sections is insufficient and that the sound transmit loss improves with the increasing cross section area of the walls. However; on the 4th climatic region, it was found that there is no need of insulation material in this region and that the sound insulation was sufficient. In addition; it was found that as the density of the lightweight concrete wall increases, the sound transmit loss improves too. In terms of frequency, it was found that the higher the frequency the better the sound insulation would become. This study found out that some walls with sufficient thermal insulation still need sound insulation especially inner areas that need extra quiteness. Sound transmission against highway traffic noise on 11 different inner activity areas of outer walls made of lightweight concrete was modelled with the ANN . 75 dB trafic noise level, frequency range of 100-4000 $\mathrm{Hz}$ and lightweight concrete walls having a density range of $400-800 \mathrm{~kg} \mathrm{~m}^{-3}$ were taken as the basis of the modeling. 2, 3, 4, and 5 neurons were used on the ANN model and the best result was achieved at the 1000 epoch on neuron 2. The actual values and ANN results were found to be consistent to each other (training data $\mathrm{R}^{2}=99.49$ and for the testing data $\mathrm{R}^{2}=99.51$ )

\section{THEORY}

The most basic definition of foamed concrete (cellular concrete, lightweight conrete) is that it is "mortar with air bubbles in it." The air content of foamed concrete may be up to $75 \%$ by volume. In general terms, foamed concrete can be described as a lightweight, free flowing material which is ideal for a wide range of applications. Foam concrete has excellent applications, not only as an insulation material, but also for other structural uses like wall blocks, floor or roof panels, sun-breakers, chajjas etc. In addition, it has sound deadening properties. Being essentially a structure composed of closed cells, it has low moisture absorption capacity. The type of lightweight concrete wall used in this study is given in Fig. 1. 


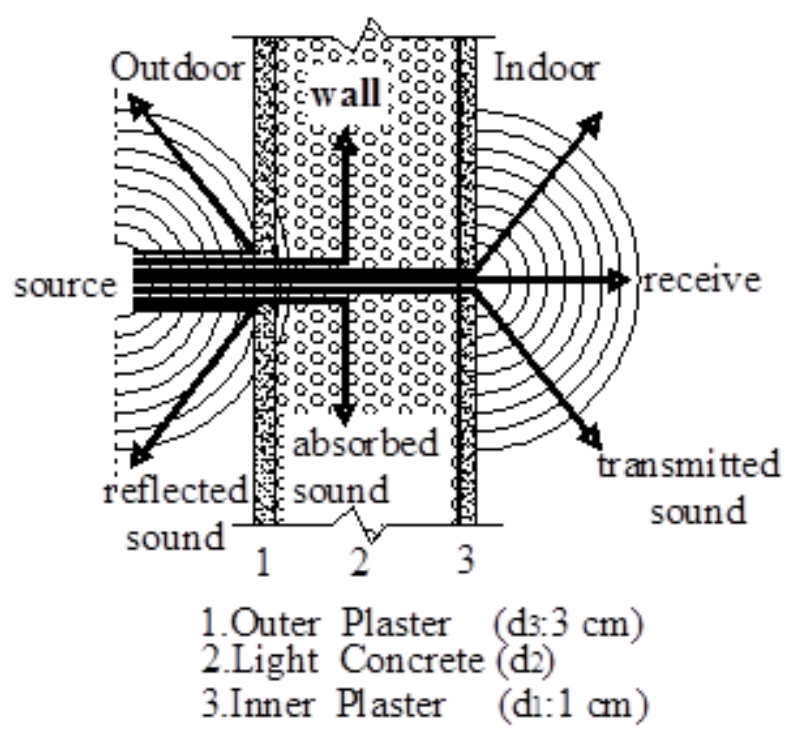

Figure 1. Lightweight concrete wall

The thermal insulation of the lightweight concrete wall, represented by the overall thermal transmittance values $U$, has to be measured to calculate the heat losses towards the ambiance. In order to be able to measure the heat losses of a building, the $U$ value (the overall thermal transmittance values) of lightweight concrete walls of the building must be calculated. $U$ is defined as follows:

$$
U=\left[R_{i}+R_{w}+R_{o}\right]^{-1}
$$

where $U$ is the overall heat transfer coefficient, $R_{i}$ and $R_{o}$, are inner and outer surfaces' thermal resistance values, $0.13 \mathrm{~m}^{2} \mathrm{~kW}^{-1}$ and $0.04 \mathrm{~m}^{2} \mathrm{~kW}^{-1}$ respectively. The $\mathrm{U}$ values used in this study are presented in Table 1. $R_{w}$ is the total thermal resistance of the lightweight concrete wall materials (TS 825, 2008). $R_{w}$ is calculated by using Eq. 2

$$
R_{w}=\left[\frac{d_{1}}{\lambda_{1}}+\frac{d_{2}}{\lambda_{2}}+\frac{d_{3}}{\lambda_{3}}\right]
$$

Table 1. $U$ and d data for climatic regions of Turkey

\begin{tabular}{|c|cc|}
\hline Climatic region & $\mathbf{U}, \mathbf{W m}^{-2} \mathbf{k}^{-\mathbf{1}}$ & $\mathbf{d} \mathbf{2}, \mathbf{c m}$ \\
\hline $\mathbf{1}$ & 0.70 & 19 \\
$\mathbf{2}$ & 0.60 & 22 \\
$\mathbf{3}$ & 0.50 & 26 \\
$\mathbf{4}$ & 0.40 & 32 \\
\hline
\end{tabular}

where $\mathrm{d}$ is the materials thickness and $\lambda$ is thermal conductivity of the material. Lightweight concrete wall thicknesses $\left(\mathrm{d}_{2}\right)$ for the 4 climatic regions of Turkey are given in Table 1 whereas the classification of walls based on their respective densities $\left(400-800 \mathrm{~kg} \mathrm{~m}^{-3}\right)$ is shown in Table 2. 
Table 2. Light concrete classes (suitable to TS EN 771- 4 and walls made of blocks with normal pattern thickness and concrete mix)

\begin{tabular}{|c|c|}
\hline Foam concrete structural plates & Density, $\mathbf{M =} \mathbf{~ k g ~ m}^{\mathbf{3}}$ \\
\hline $\mathbf{1}$ & 400 \\
$\mathbf{2}$ & 500 \\
$\mathbf{3}$ & 600 \\
$\mathbf{4}$ & 700 \\
$\mathbf{5}$ & 800 \\
\hline
\end{tabular}

The sound transmission loss (STL) between the source and receiving rooms are plotted on a graph by frequency and sound level in decibels. STL $\left(R_{0}\right)$ can be calculated from Eq. 3

$$
R_{0}=20 \log (f . M)-45
$$

where $R_{0}$ is the sound reduction index. Here $M$ is the surface density of board material and $f$ is the frequency (Özer, 1979). The difference (L) between noise criteria range for steady background (Table 3) and the sound transmitted from the lightweight concrete wall to the indoor areas can be calculated with the below equation:

$$
\Delta L=L_{m}-\left(L_{o}-R_{0}\right)
$$

where $L_{m}$ is the suggested noise criteria in various indoor occupied functional areas, $L_{o}$ is the main artery noise level, $R_{o}$ is the sound reduction index, TS is the transmitted sound. If Eq. 4 is rearranged according to TS, then equation 5 can be written as below:

$$
\Delta L=L_{m}-T S
$$

\section{DEVELOPED ANN FOR THE SOUND TRANSMISSION OF LIGHTWEIGHT CONCRETE WALLS AGAINST HIGHWAY NOISES}

ANNs mimic somewhat the learning process of a human brain. Instead of complex rules and mathematical routines, ANNs are able to learn the key information patterns within a multidimensional information domain. In addition, the inherently noisy data do not seem to present a problem, since they are neglected (Kalogirou and Bojic, 2000) . Artificial neural network is a type of artificial intelligence technique that mimics the behavior of human brain. It can approximate a nonlinear relationship between the input variables and the output of a complicated system (Yang et al., 2005 ).

In this study, light concrete walls' sound transmissions were modelled with ANN for 11 different buildings subjected to highway noises at the level of 75 decibals. Due to the fact that dimensioning of outer shell of all thermal insulated buildings in Turkey is to be based on the TSE 825 standard, the modeling of the ANN used for this study has been based on this same standard too. As ANN input parameters $d_{2}, f, M$ were used, while the TS was the output parameter. Where $d_{2}$ represents wall thickness; $M$ is wall density and $\mathrm{f}$, frequency. During modeling, these values were assigned: $\mathrm{d}_{2}=19,22$, 26, $32 \mathrm{~cm}, \mathrm{M}=400,500,600,700,800 \mathrm{~kg} \mathrm{~m}^{-3}$, and $\mathrm{f}=100,200,500,1000,2000,4000 \mathrm{~Hz}$. The thickness of wall $\left(\mathrm{d}_{2}\right)$ is calculated from Eq. 2. 120 data sets were obtained from the data list and $60\left(1^{\text {st }}\right.$ and $3^{\text {rd }}$ climatic regions) of them were chosen for training, whereas 30 ( $2^{\text {nd }}$ climatic region) of them were chosen for testing. 30 data sets ( $4^{\text {th }}$ climatic region) were estimated with the ANN modeling. All the data were 
chosen randomly and normalized within the range of $0-1$ for the ANN modeling by using the operator given in Eq. 6.

Table 3. Recommended category classification and suggested noise criteria range for steady background noise as heard in various indoor occupied functional activity areas

\begin{tabular}{|lcc|}
\hline \multicolumn{1}{|c|}{ Type of space (and acoustical requirements) } & NC Curve & $\begin{array}{c}\text { Approximate } \\
\text { Lm, }\end{array}$ \\
dB
\end{tabular}

$$
Z=\frac{Z_{N-} Z_{\min }}{Z_{\max -} Z_{\min }}
$$

where $Z_{N}$ is the normalized value of a variable, $Z$ is a real value in a paremeter, $Z_{\max }$ and $Z_{\min }$ are the maximum and minimum values of $\mathrm{Z}$, respectively. In Fig. 2 ANN architecture used for $\mathrm{d}_{2}$ is schematically shown. The ANN model developed on Matlab software was tested at the values of 100, 250, 500, 1000 epochs for 2, 3, 4 and 5 neurons respectively. The best result was found at neuron 2 .

\section{RESULTS AND DISCUSSION}

Excessive noise seriously harms human health and interferes with people's daily activities at school, at work, at home and during leisure time. It can disturb sleep, cause cardiovascular and psychophysiological effects, reduce performance and provoke annoyance responses and changes in social behaviour. Traffic noise alone is harming the health of almost every third person in the WHO European Region. The 2009 WHO night noise guidelines for Europe provide both evidence and recommendations that countries can easily use to introduce targeted limits for night noise. WHO/Europe uses the evidence on the health effects of noise to identify the needs of vulnerable groups and to offer technical and policy guidance to protect health (WHO, 2012). 


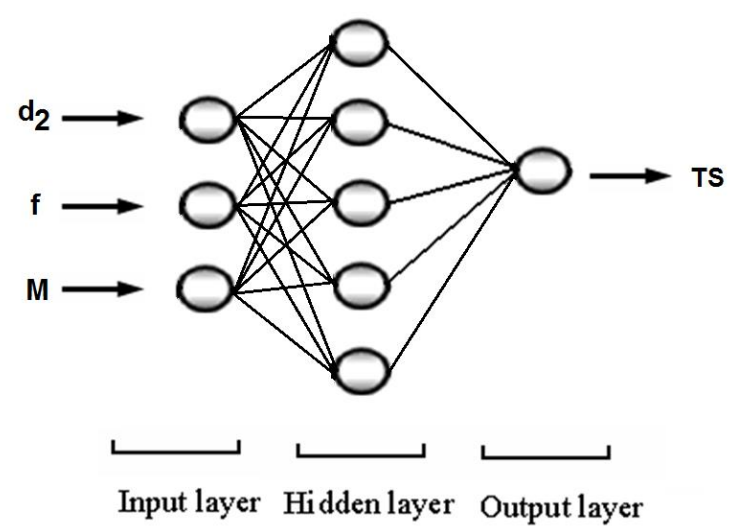

Figure 2. ANN architecture used for $\mathrm{d}_{2}$

Noise ranges that are considered to cause no health damages at different occusions are presented in Table 3. (Beranek and Ver, 1992) Sound insulation is necessary in areas that receive unacceptably high levels of highway noises and the values for the noise climate found in situations where traffic noise predominates are presented in Table 4 (Croome, 1992).

Table 4. Noise climate found in situations where traffic noise predominates

\begin{tabular}{|c|c|c|c|}
\hline \multirow{2}{*}{ Group } & \multirow{2}{*}{ Location } & \multicolumn{2}{|c|}{ Noise climate, $\mathrm{dB}$} \\
\hline & & Day & Night \\
\hline A & Arterial roads with many heavy vehicles and buses (kerbside) & $80-68$ & $68-50$ \\
\hline B & $\begin{array}{l}\text { (i) Major roads with heavy traffic and buses } \\
\text { (ii) Side roads within } 14-18 \mathrm{~m} \text { of A or B group road }\end{array}$ & $75-63$ & $61-48$ \\
\hline $\mathrm{C}$ & $\begin{array}{l}\text { (i) Residential roads } \\
\text { (ii) Side roads within } 14-18 \mathrm{~m} \text { of heavy traffic routes } \\
\text { (iii) Courtyards of blocks of flats screened from direct view of } \\
\text { heavy traffic }\end{array}$ & $70-60$ & $54-44$ \\
\hline D & Residential roads with local traffic only & $65-57$ & $52-44$ \\
\hline $\mathbf{E}$ & $\begin{array}{l}\text { (i) Minor roads } \\
\text { (ii) Gardens of houses with traffic routes more than } 61 \mathrm{~m} \text { distant }\end{array}$ & $60-52$ & $48-43$ \\
\hline $\mathbf{F}$ & $\begin{array}{l}\text { Parks, courtyards, gardens in residential areas well away from } \\
\text { traffic routes }\end{array}$ & $55-50$ & $46-41$ \\
\hline
\end{tabular}

ANNs have been used widely in many application areas. Researchers have been applying the ANN technique successfully in various fields of mathematics, engineering, medicine, economics and many other areas. ANNs have been trained to overcome the limitations of the conventional approaches to solve complex problems. This technique learns from given examples by constructing an input-output mapping in order to perform predictions (Kalogirou, 2000). In this study, analysis was conducted on sound transmission loss of single layered lightweight concrete walls used widely in Turkey and that provide sufficient thermal insulation (based on TSE standards (Tables 5-8), then the transimitted sound was modeled with ANN (Figs.3-6). The analysis of the lightweight concrete walls based on their noise level threshold and the results of the ANN model were investigated in 4 situations. 


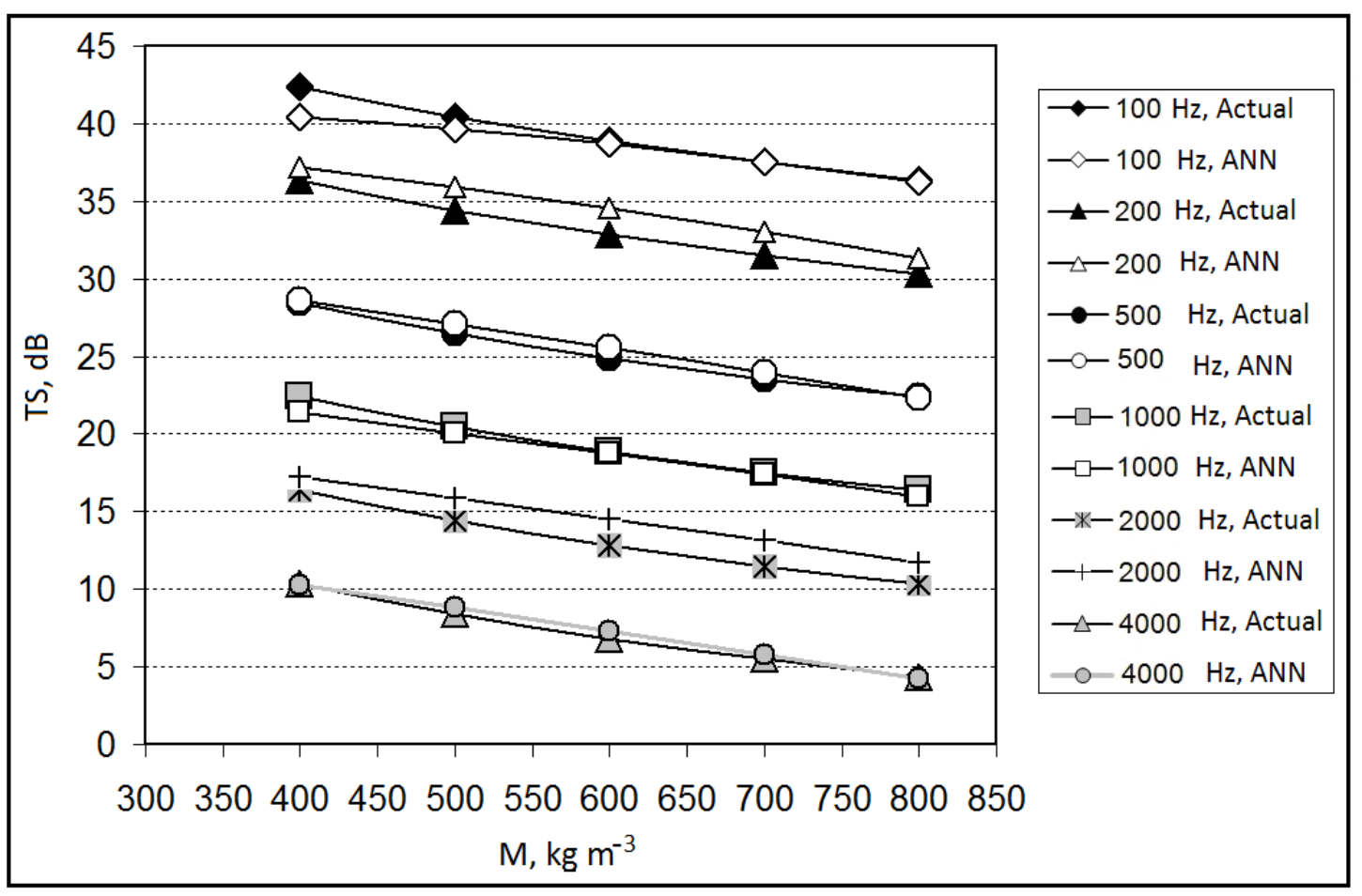

Figure 3. Comparison of actual data with ANN for TS, based on frequency (training-1 ${ }^{\text {st }}$ climatic region)

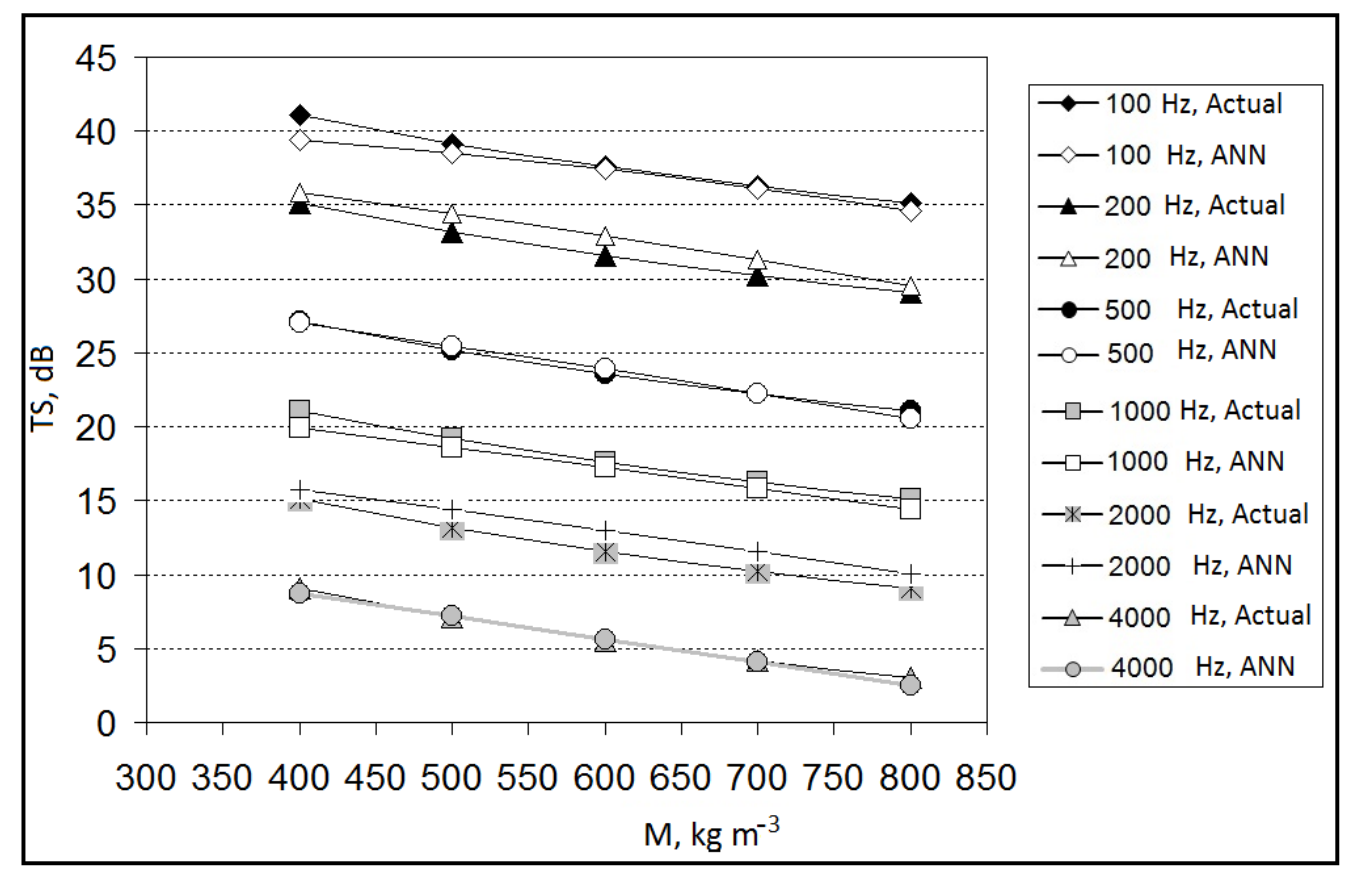

Figure 4. Comparison of actual data with ANN for TS, based on frequencies (test-2 $2^{\text {nd }}$ climatic region) 


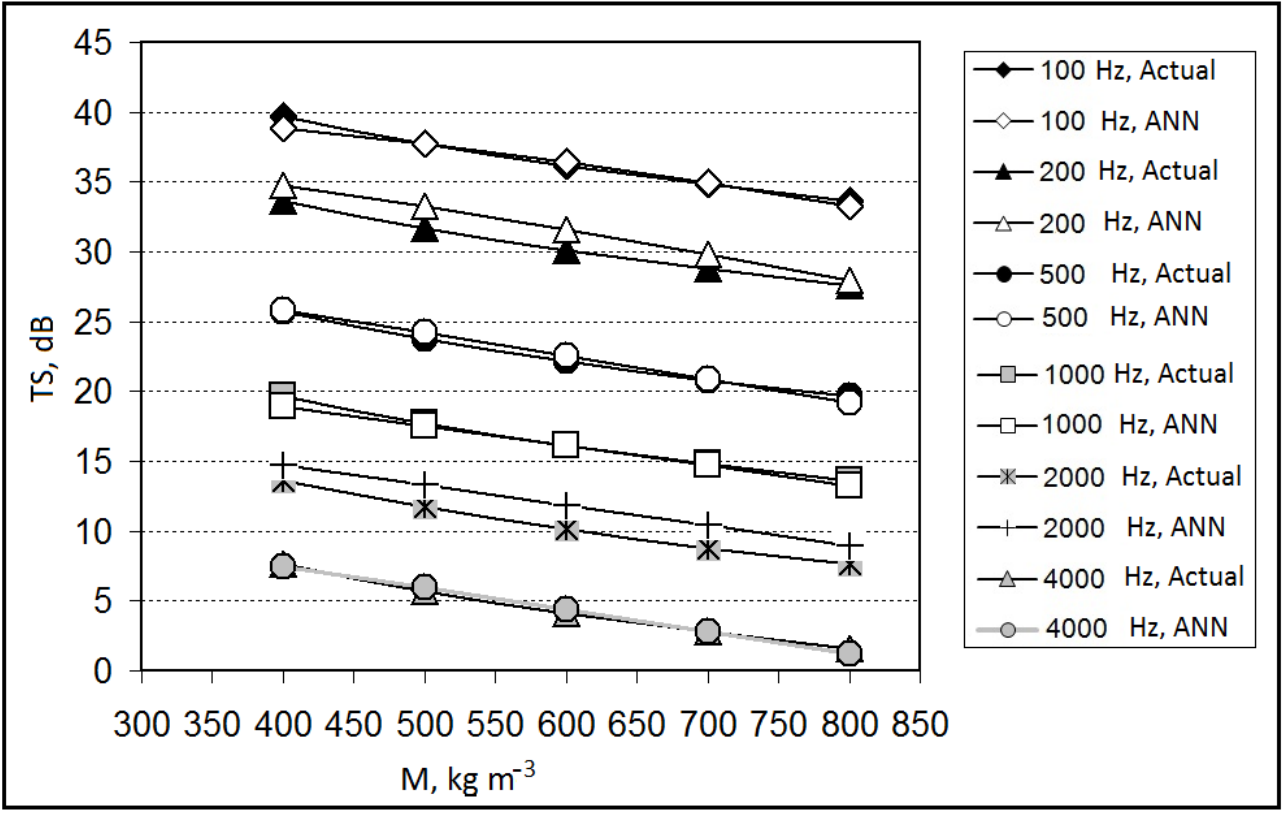

Figure 5. Comparison of actual data with ANN for transmitted sound, based on frequency (training- $3^{\text {rd }}$ climatic region)

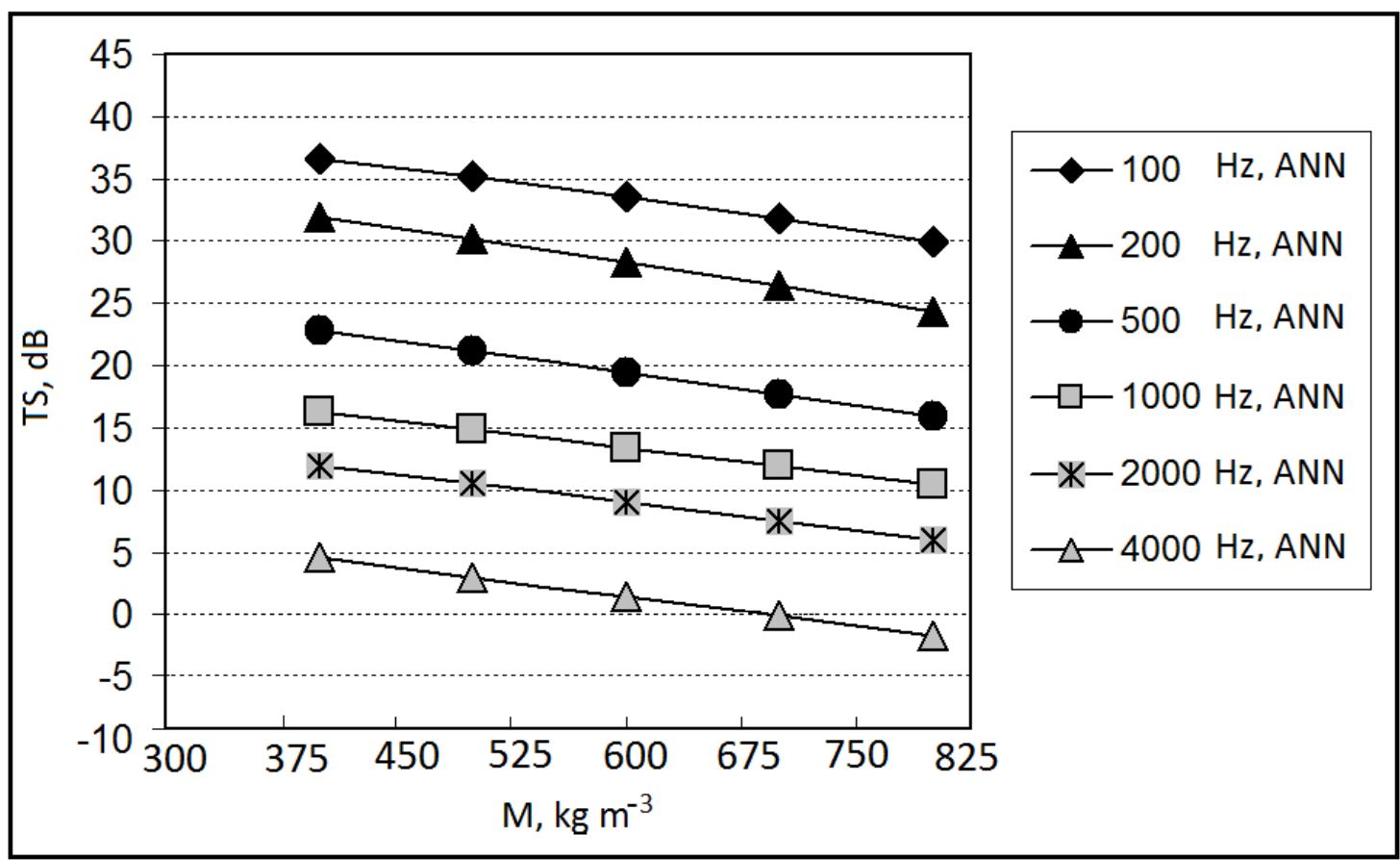

Figure 6. Variations of TS with respect to frequency (ANN-prediction- $4^{\text {th }}$ climatic region)

\section{Situation for the 1st Climatic Region of Wall Thickness - $L_{m}$ for STL}

According to TSE 825 standard, the lightweight concrete wall thickness sufficient for thermal insulation in the 1 st climatic region is $\mathrm{d}_{2}=19 \mathrm{~cm}$ (Table 1 ). The values of wall thickness $\mathrm{d}_{2}$, density $\mathrm{M}$ and frequency $f$, for transmitted sound (TS) analysis $(-L)$ in the $1^{\text {st }}$ climatic region are presented in Table 5 . The worst case for the $1^{\text {st }}$ climatic region is observed between sections 1 and 5 as given in Table 3 . The 
values for the $1^{\text {st }}$ spaces are as given below; $\rightarrow L 1 / 1$, min value $=-24.38 \mathrm{~dB}, \mathrm{f}=100 \mathrm{~Hz}, \mathrm{M}=400 \mathrm{~kg} \mathrm{~m}^{-3} ; \quad \rightarrow L 1 / 1, \mathrm{crv}$ $=0.48 \mathrm{~dB}, \mathrm{f}=1000 \mathrm{~Hz}, \mathrm{M}=700 \mathrm{~kg} \mathrm{~m}^{-3} ; \quad \quad-\mathrm{L} / 1$, max value $=13.68 \mathrm{~dB}, \mathrm{f}=4000 \mathrm{~Hz}, \mathrm{M}=800 \mathrm{~kg} \mathrm{~m}^{-3}$; As for sections in the $2^{\text {nd }}$ spaces, the values are; $\checkmark L_{1 / 2}$, min value $=-19.38 \mathrm{~dB}, \mathrm{f}=100 \mathrm{~Hz}, \mathrm{M}=400 \mathrm{~kg} \mathrm{~m}^{-3} ; \nleftarrow-L_{1 / 2, \mathrm{crv}}=0.62 \mathrm{~dB}, \mathrm{f}=500$ $\mathrm{Hz}, \mathrm{M}=800 \mathrm{~kg} \mathrm{~m}^{-3} ;+L 1 / 2$, max value $=18.68 \mathrm{~dB}, \mathrm{f}=4000 \mathrm{~Hz}, \mathrm{M}=800 \mathrm{~kg} \mathrm{~m}^{-3}$; in the $3^{\text {rd }}$ spaces were found to bear these values; $+L 1 / 3$, min value $=-14.38 \mathrm{~dB}, \mathrm{f}=100 \mathrm{~Hz}, \mathrm{M}=400 \mathrm{~kg} \mathrm{~m}^{-3} ;-L 1 / 3, \mathrm{crv}=1.53 \mathrm{~dB}, \mathrm{f}=500 \mathrm{~Hz}, \mathrm{M}=500 \mathrm{~kg} \mathrm{~m}^{-3}$; $-L_{1 / 3}$, max value $=23.68 \mathrm{~dB}, \mathrm{f}=4000 \mathrm{~Hz}, \mathrm{M}=800 \mathrm{~kg} \mathrm{~m}^{-3}$; the study also found that the $4^{\text {th }}$ spaces exhibit these entities; $\checkmark L_{1 / 4}$, min value $=-9.38 \mathrm{~dB}, \mathrm{f}=100 \mathrm{~Hz}, \mathrm{M}=400 \mathrm{~kg} \mathrm{~m}^{-3} ; \quad-L_{1 / 4, \mathrm{crv}}=0.16 \mathrm{~dB}, \mathrm{f}=200 \mathrm{~Hz}, \mathrm{M}=600 \mathrm{~kg} \mathrm{~m}^{-3} ; \nleftarrow L_{1 / 4,}$ max value $=28.68 \mathrm{~dB}, \mathrm{f}=4000 \mathrm{~Hz}, \mathrm{M}=800 \mathrm{~kg} \mathrm{~m}^{-3}$; spaces in the $5^{\text {th }}$ were found to have these values; $\rightarrow \mathrm{L} 1 / 5, \min$ value $=-4.38 \mathrm{~dB}, \mathrm{f}=100 \mathrm{~Hz}, \mathrm{M}=400 \mathrm{~kg} \mathrm{~m}^{-3} ; \quad-\mathrm{L} 1 / 5, \mathrm{crv}=0.48 \mathrm{~dB}, \mathrm{f}=100 \mathrm{~Hz}, \mathrm{M}=700 \mathrm{~kg} \mathrm{~m}^{-3} ; \quad L_{1 / 5}$, max value $=33.68 \mathrm{~dB}$, $\mathrm{f}=4000 \mathrm{~Hz}, \mathrm{M}=800 \mathrm{~kg} \mathrm{~m}^{-3}$. No negative cases for the $1^{\text {st }}$ climatic region were found between $6-11$ spaces as listed in Table 3 where there is steady background noise as heard in various indoor occupied functional activity areas. The best cases for spaces $6-11$ were observed at $\mathrm{f}=4000 \mathrm{~Hz}$ ve $\mathrm{M}=800 \mathrm{~kg} \mathrm{~m}^{-3}$. These are; $\rightarrow L 1 / 6$, max value $=43.68 \mathrm{~dB}, \sim L 1 / 7$, max value $=48.68 \mathrm{~dB}, \sim L 1 / 8$, max value $=53.68 \mathrm{~dB},+L 1 / 9$, max value $=58.68 \mathrm{~dB}$, $\checkmark L 1 / 10$, max value $=63.68 \mathrm{~dB}, \nsucc L 1 / 11$, max value $=73.68 \mathrm{~dB}$. Fig.3 shows variation of $A N N$ data and actual data with respect to frequency and TS for the $1^{\text {st }}$ climatic region.

Table 5. $\rightarrow$ for lightweight concrete wall in 1st climatic region

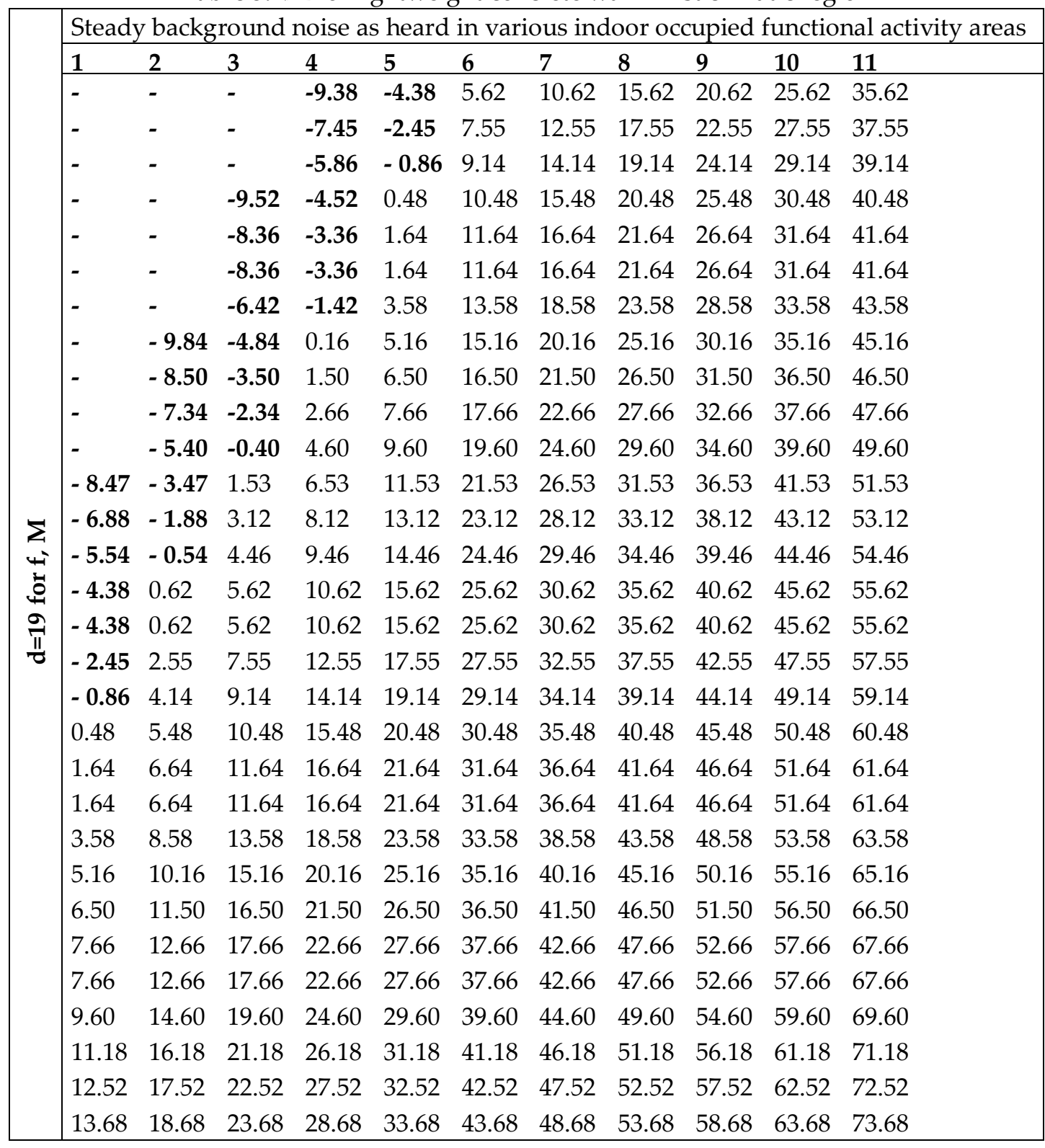




\section{Situation for the 2nd Climatic Region of Wall Thickness - $L_{m}$ for STL}

The $2^{\text {nd }}$ climatic region according to the TSE 825 standard should have lightweight concrete wall thickness of $22 \mathrm{~cm}\left(\mathrm{~d}_{2}=22 \mathrm{~cm}\right.$-see Table 1) in order to achieve sufficient thermal insulation. The TS analysis $(-L)$ for the $2^{\text {nd }}$ climatic region in terms of wall thickness $d_{2}$, density $M$ and frequency, $f$ is presented in Table 6.

The worst case for the $2^{\text {nd }}$ climatic region as given in Table 3 occurred on sections 1-5. The values for the $1^{\text {st }}$ spaces were found to be; $\rightarrow L 2 / 1$, min value $=-23.11 \mathrm{~dB}, \mathrm{f}=100 \mathrm{~Hz}, \mathrm{M}=400 \mathrm{~kg} \mathrm{~m}^{-3} ;-L 2 / 1, \mathrm{crv} 0.41 \mathrm{~dB}, \mathrm{f}=1000$ $\mathrm{Hz}, \mathrm{M}=600 \mathrm{~kg} \mathrm{~m}^{-3} ; \quad-L 2 / 1$, max value $=14.95, \mathrm{f}=4000 \mathrm{~Hz}, \mathrm{M}=800 \mathrm{~kg} \mathrm{~m}^{-3}$; for the $2^{\text {nd }}$ spaces, the values were; $r L 2 / 2$, min value $=-18.11 \mathrm{~dB}, \mathrm{f}=100 \mathrm{~Hz}, \mathrm{M}=400 \mathrm{~kg} \mathrm{~m}^{-3} ; \forall \mathrm{L} / 2 / 2$, crv $=0.73 \mathrm{~dB}, \mathrm{f}=500 \mathrm{~Hz}, \mathrm{M}=700 \mathrm{~kg} \mathrm{~m}^{-3} ; \quad-L_{2 / 2}$, max value $=19.95$ $\mathrm{dB}, \mathrm{f}=4000 \mathrm{~Hz}, \mathrm{M}=800 \mathrm{~kg} \mathrm{~m}^{-3}$; the $3^{\text {rd }}$ spaces had these values; $\because \mathrm{L} / 3 / 3$, min value $=-13.11 \mathrm{~dB}, \mathrm{f}=100 \mathrm{~Hz}, \mathrm{M}=400 \mathrm{~kg}$ $\mathrm{m}^{-3} ; \nleftarrow \mathrm{L}_{2 / 3, \mathrm{crv}}=0.87 \mathrm{~dB}, \mathrm{f}=500 \mathrm{~Hz}, \mathrm{M}=400 \mathrm{~kg} \mathrm{~m}^{-3} ; \nleftarrow \mathrm{L}_{2 / 3}$, max value $=24.95 \mathrm{~dB}, \mathrm{f}=4000 \mathrm{~Hz}, \mathrm{M}=800 \mathrm{~kg} \mathrm{~m}^{-3} ;$ values for the $4^{\text {th }}$ spaces were; $\checkmark L 2 / 4$, min value $=-8.11 \mathrm{~dB}, \mathrm{f}=100 \mathrm{~Hz}, \mathrm{M}=400 \mathrm{~kg} \mathrm{~m}^{-3} ; \sim L 2 / 4, \mathrm{crv}=1.43 \mathrm{~dB}, \mathrm{f}=200 \mathrm{~Hz}, \mathrm{M}=600$ $\mathrm{kg} \mathrm{m}^{-3} ; \nsucc L 2 / 4$, max value $=29.95 \mathrm{~dB}, \mathrm{f}=4000 \mathrm{~Hz}, \mathrm{M}=800 \mathrm{~kg} \mathrm{~m}^{-3}$; the $5^{\text {th }}$ space's values were $; \quad-L 2 / 5$, min value $=-3.11$ $\mathrm{dB}, \mathrm{f}=100 \mathrm{~Hz}, \mathrm{M}=400 \mathrm{~kg} \mathrm{~m}^{-3} ; \quad-L_{2 / 5, \mathrm{crv}}=0.41 \mathrm{~dB}, \mathrm{f}=100 \mathrm{~Hz}, \mathrm{M}=600 \mathrm{~kg} \mathrm{~m}^{-3} ; \nleftarrow \mathrm{L}_{2 / 5}$, max value $=34.95 \mathrm{~dB}, \mathrm{f}=4000$ $\mathrm{Hz}, \mathrm{M}=800 \mathrm{~kg} \mathrm{~m}^{-3}$. In terms of sound transmission for the $2^{\text {nd }}$ climatic region, (Table 3) no negative observation was recorded for spaces 6-11. The best case on these spaces (6-11) exhibited these conditions, $\mathrm{f}=4000 \mathrm{~Hz}$ ve $\mathrm{M}=800 \mathrm{~kg} \mathrm{~m}^{-3}$, Where the values were; $\checkmark L_{2 / 6}$, max value $=44.95 \mathrm{~dB},-L 2 / 7$, max value $=49.95 \mathrm{~dB}, \quad-L_{2 / 8}$, max value $=54.95 \mathrm{~dB}, \neg L 2 / 9$, $\max$ value $=59.95 \mathrm{~dB},-L 2 / 10$, max value $=64.95 \mathrm{~dB},-L 2 / 11$, max value $=74.95 \mathrm{~dB}$. In Fig. 4 , variation of actual and ANN data with respect to frequency and TS for the $2^{\text {nd }}$ climatic region is presented.

\section{Situation for 3rd Climatic Region of Wall Thickness - $L_{m}$ for STL}

According to the TSE 825 standard, the thickness of lightweight concrete wall sufficient for thermal insulation for the $3^{\text {rd }}$ climatic region is $d_{2}=26 \mathrm{~cm}$ (Table 1). The values of $d_{2}, M$ and $f$ for TS analysis $(-L)$ for the $3^{\text {rd }}$ climatic region is presented in Table 7 .

$\mathrm{f}=200 \mathrm{~Hz}, \mathrm{M}=800 \mathrm{~kg} / \mathrm{m}^{3} ; \quad \mathrm{L} 3 / 3$, max value $=26.40 \mathrm{~dB}, \mathrm{f}=4000 \mathrm{~Hz}, \mathrm{M}=800 \mathrm{~kg} \mathrm{~m}^{-3}$; as for the $4^{\text {th }}$ spaces, the values were; $\checkmark L 3 / 4$, min value $=-6.66 \mathrm{~dB}, \mathrm{f}=100 \mathrm{~Hz}, \mathrm{M}=400 \mathrm{~kg} \mathrm{~m}^{-3} ; \quad \mathrm{L}_{3 / 4, \mathrm{crv}}=1.30 \mathrm{~dB}, \mathrm{f}=200 \mathrm{~Hz}, \mathrm{M}=500 \mathrm{~kg} \mathrm{~m}^{-3} ; \nleftarrow \mathrm{L}_{3 / 4, \max }$ value $=31.40 \mathrm{~dB}, \mathrm{f}=4000 \mathrm{~Hz}, \mathrm{M}=800 \mathrm{~kg} \mathrm{~m}^{-3}$; values for the $5^{\text {th }}$ spaces were found to be; $\because L 3 / 5$, $\min$ value $=-1.66$ $\mathrm{dB}, \mathrm{f}=100 \mathrm{~Hz}, \mathrm{M}=400 \mathrm{~kg} \mathrm{~m}^{-3} ; \quad-\mathrm{L}_{3 / 5, \mathrm{crv}}=0.28 \mathrm{~dB}, \mathrm{f}=100 \mathrm{~Hz}, \mathrm{M}=500 \mathrm{~kg} \mathrm{~m}^{-3} ; \nleftarrow L 3 / 5$, max value $=36.40 \mathrm{~dB}, \mathrm{f}=4000$ $\mathrm{Hz}, \mathrm{M}=800 \mathrm{~kg} \mathrm{~m}^{-3}$. As for the $3^{\text {rd }}$ climatic region, among the sections 6-11 in Table 3, no negative aspects in terms of sound level were found for sections $6^{\text {th }}-11^{\text {th }}$ whereas the best case for 6-11 spaces in the $3^{\text {rd }}$ climatic region took space under these conditions of frequency and density, $\mathrm{f}=4000 \mathrm{~Hz}$ and $\mathrm{M}=800 \mathrm{~kg} \mathrm{~m}^{-3}$ respectively. Here, it is found that; $\nleftarrow L_{3 / 6}$, max value $=46.40 \mathrm{~dB},-L 3 / 7$, max value $=51.40 \mathrm{~dB}, \nsucc \mathrm{L}_{3 / 8}$, max value $=56.40$ $\mathrm{dB}, \rightarrow L 3 / 9$, max value $=61.40 \mathrm{~dB},+L 3 / 10$, max value $=66.40 \mathrm{~dB},+L 3 / 11$, max value $=76.40 \mathrm{~dB}$. Fig. 5 shows variation of ANN and actual data for the $3^{\text {rd }}$ climatic region based on frequency and TS.

The most negative case for the $3^{\text {rd }}$ climatic region appears on sections 1-5 as shown on Table 3 . For the $1^{\text {st }}$ spaces, the following values were found; $\checkmark L 3 / 1$, min value $=-21.66 \mathrm{~dB}, \mathrm{f}=100 \mathrm{~Hz}, \mathrm{M}=400 \mathrm{~kg} \mathrm{~m}^{-3} ; \quad-\mathrm{L} / 1 / \mathrm{crv}=$ $0.28 \mathrm{~dB}, \mathrm{f}=1000 \mathrm{~Hz}, \mathrm{M}=500 \mathrm{~kg} \mathrm{~m}^{-3} ;+L 3 / 1$, max value $=16.40 \mathrm{~dB}, \mathrm{f}=4000 \mathrm{~Hz}, \mathrm{M}=800 \mathrm{~kg} \mathrm{~m}^{-3} ;$ For the $2^{\text {nd }}$ spaces, the values found were $\checkmark L_{3 / 2}$, min value $=-16.66 \mathrm{~dB}, \mathrm{f}=100 \mathrm{~Hz}, \mathrm{M}=400 \mathrm{~kg} \mathrm{~m}^{-3} ; \nleftarrow \mathrm{L}_{3 / 2, \mathrm{crv}}=0.84 \mathrm{~dB}, \mathrm{f}=500 \mathrm{~Hz}$, $\mathrm{M}=600 \mathrm{~kg} \mathrm{~m}^{-3} ;-\mathrm{L} 3 / 2$, max value $=21.40 \mathrm{~dB}, \mathrm{f}=4000 \mathrm{~Hz}, \mathrm{M}=800 \mathrm{~kg} \mathrm{~m}^{-3}$; the $3^{\text {rd }}$ spaces had; $\nsucc \mathrm{L} 3 / 3$, min value $=-11.66$ $\mathrm{dB}, \mathrm{f}=100 \mathrm{~Hz}, \mathrm{M}=400 \mathrm{~kg} \mathrm{~m}^{-3} ; \quad+\mathrm{L} 3 / 3, \mathrm{crv}=0.38 \mathrm{~dB}$, 
Table 6. $+L$ for lightweight concrete wall in 2 nd climatic region

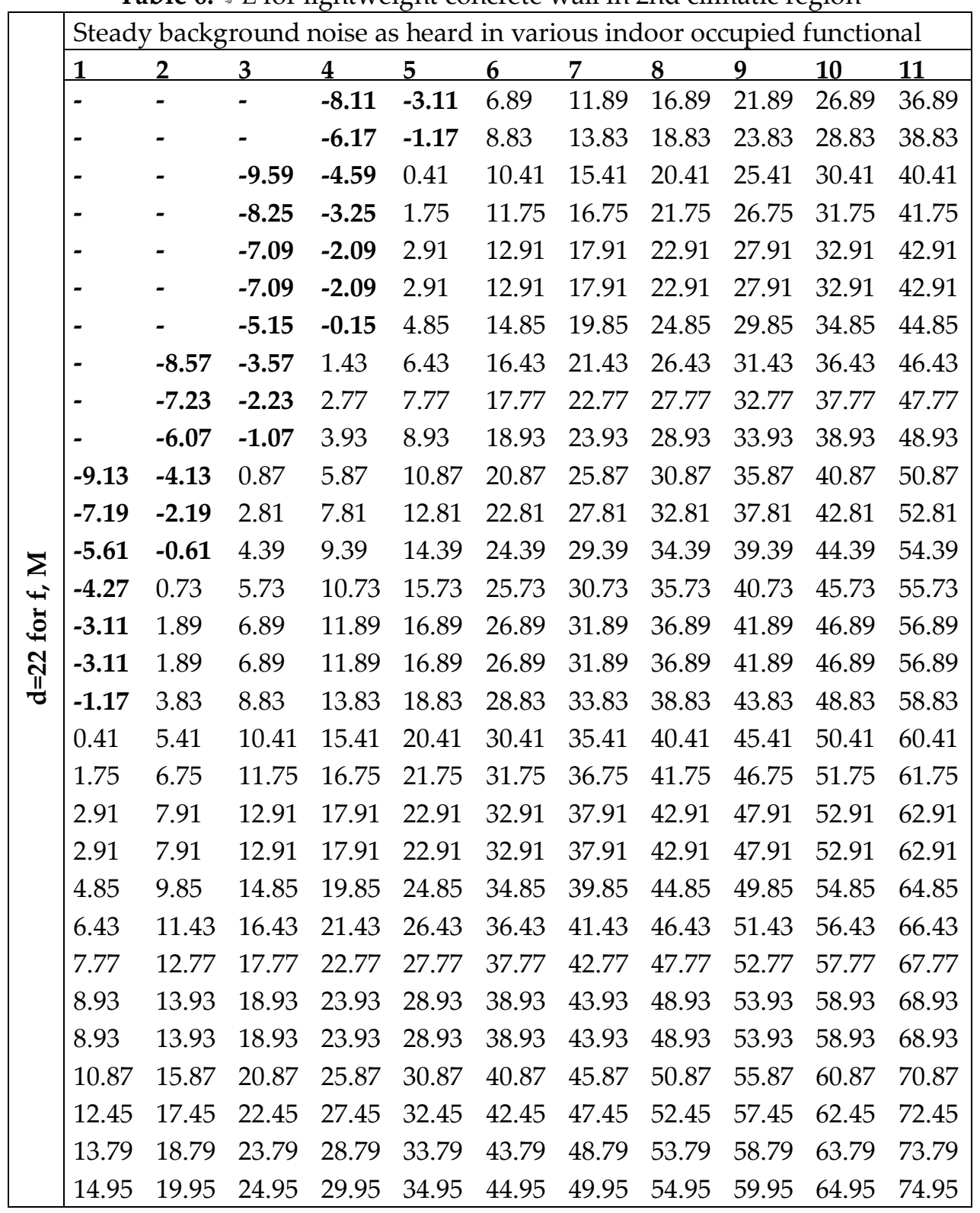


Table 7. $+L$ for lightweight concrete wall in 3rd climatic region

\begin{tabular}{|c|c|c|c|c|c|c|c|c|c|c|c|}
\hline & \multicolumn{11}{|c|}{ Steady background noise as heard in various indoor occupied functional activity areas } \\
\hline & 1 & 2 & 3 & 4 & 5 & 6 & 7 & 8 & 9 & 10 & 11 \\
\hline \multirow{30}{*}{ 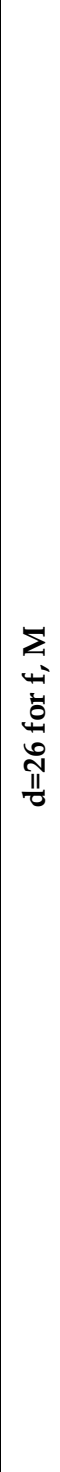 } & -21.66 & -16.66 & -11.66 & -6.66 & -1.66 & 8.34 & 13.34 & 18.34 & 23.34 & 28.34 & 38.34 \\
\hline & -19.72 & -14.72 & -9.72 & -4.72 & 0.28 & 10.28 & 15.28 & 20.28 & 25.28 & 30.28 & 40.28 \\
\hline & -18.14 & -13.14 & -8.14 & -3.14 & 1.86 & 11.86 & 16.86 & 21.86 & 26.86 & 31.86 & 41.86 \\
\hline & -16.80 & -11.80 & -6.80 & -1.80 & 3.20 & 13.20 & 18.20 & 23.20 & 28.20 & 33.20 & 43.20 \\
\hline & -15.64 & -10.64 & -5.64 & -0.64 & 4.36 & 14.36 & 19.36 & 24.36 & 29.36 & 34.36 & 44.36 \\
\hline & -15.64 & -10.64 & -5.64 & -0.64 & 4.36 & 14.36 & 19.36 & 24.36 & 29.36 & 34.36 & 44.36 \\
\hline & -13.70 & -8.70 & -3.70 & 1.30 & 6.30 & 16.30 & 21.30 & 26.30 & 31.30 & 36.30 & 46.30 \\
\hline & -12.12 & -7.12 & -2.12 & 2.88 & 7.88 & 17.88 & 22.88 & 27.88 & 32.88 & 37.88 & 47.88 \\
\hline & -10.78 & -5.78 & -0.78 & 4.22 & 9.22 & 19.22 & 24.22 & 29.22 & 34.22 & 39.22 & 49.22 \\
\hline & -9.62 & -4.62 & 0.38 & 5.38 & 10.38 & 20.38 & 25.38 & 30.38 & 35.38 & 40.38 & 50.38 \\
\hline & -7.68 & -2.68 & 2.32 & 7.32 & 12.32 & 22.32 & 27.32 & 32.32 & 37.32 & 42.32 & 52.32 \\
\hline & -5.74 & -0.74 & 4.26 & 9.26 & 14.26 & 24.26 & 29.26 & 34.26 & 39.26 & 44.26 & 54.26 \\
\hline & -4.16 & 0.84 & 5.84 & 10.84 & 15.84 & 25.84 & 30.84 & 35.84 & 40.84 & 45.84 & 55.84 \\
\hline & -2.82 & 2.18 & 7.18 & 12.18 & 17.18 & 27.18 & 32.18 & 37.18 & 42.18 & 47.18 & 57.18 \\
\hline & -1.66 & 3.34 & 8.34 & 13.34 & 18.34 & 28.34 & 33.34 & 38.34 & 43.34 & 48.34 & 58.34 \\
\hline & -1.66 & 3.34 & 8.34 & 13.34 & 18.34 & 28.34 & 33.34 & 38.34 & 43.34 & 48.34 & 58.34 \\
\hline & 0.28 & 5.28 & 10.28 & 15.28 & 20.28 & 30.28 & 35.28 & 40.28 & 45.28 & 50.28 & 60.28 \\
\hline & 1.86 & 6.86 & 11.86 & 16.86 & 21.86 & 31.86 & 36.86 & 41.86 & 46.86 & 51.86 & 61.86 \\
\hline & 3.20 & 8.20 & 13.20 & 18.20 & 23.20 & 33.20 & 38.20 & 43.20 & 48.20 & 53.20 & 63.20 \\
\hline & 4.36 & 9.36 & 14.36 & 19.36 & 24.36 & 34.36 & 39.36 & 44.36 & 49.36 & 54.36 & 64.36 \\
\hline & 4.36 & 9.36 & 14.36 & 19.36 & 24.36 & 34.36 & 39.36 & 44.36 & 49.36 & 54.36 & 64.36 \\
\hline & 6.30 & 11.30 & 16.30 & 21.30 & 26.30 & 36.30 & 41.30 & 46.30 & 51.30 & 56.30 & 66.30 \\
\hline & 7.88 & 12.88 & 17.88 & 22.88 & 27.88 & 37.88 & 42.88 & 47.88 & 52.88 & 57.88 & 67.88 \\
\hline & 9.22 & 14.22 & 19.22 & 24.22 & 29.22 & 39.22 & 44.22 & 49.22 & 54.22 & 59.22 & 69.22 \\
\hline & 10.38 & 15.38 & 20.38 & 25.38 & 30.38 & 40.38 & 45.38 & 50.38 & 55.38 & 60.38 & 70.38 \\
\hline & 10.38 & 15.38 & 20.38 & 25.38 & 30.38 & 40.38 & 45.38 & 50.38 & 55.38 & 60.38 & 70.38 \\
\hline & 12.32 & 17.32 & 22.32 & 27.32 & 32.32 & 42.32 & 47.32 & 52.32 & 57.32 & 62.32 & 72.32 \\
\hline & 13.90 & 18.90 & 23.90 & 28.90 & 33.90 & 43.90 & 48.90 & 53.90 & 58.90 & 63.90 & 73.90 \\
\hline & 15.24 & 20.24 & 25.24 & 30.24 & 35.24 & 45.24 & 50.24 & 55.24 & 60.24 & 65.24 & 75.24 \\
\hline & 16.40 & 21.40 & 26.40 & 31.40 & 36.40 & 46.40 & 51.40 & 56.40 & 61.40 & 66.40 & 76.40 \\
\hline
\end{tabular}

\section{Situation for the 4th Climatic Region of Wall Thickness - $L_{m}$ for STL}

$32 \mathrm{~cm}$ is the acceptable thickness of a lightweight concrete wall for thermal insulation for the $4^{\text {th }}$ climatic region in TSE 825 (Table 1). TS analysis $(-L)$ of $\mathrm{d}_{2}, \mathrm{M}$ and $\mathrm{f}$, for the $4^{\text {th }}$ climatic region is shown on Table 8 . The $4^{\text {th }}$ climatic region has had its worst case between sections 1 and 4 (Table 3 ). Here, the $1^{\text {st }}$ spaces acquired the values of $; \quad L 4 / 1$, min value $=-19.86 \mathrm{~dB}, \mathrm{f}=100 \mathrm{~Hz}, \mathrm{M}=400 \mathrm{~kg} \mathrm{~m}^{-3} ;+L 4 / 1$, crv $=0.14 \mathrm{~dB}, \mathrm{f}=500$ $\mathrm{Hz}, \mathrm{M}=800 \mathrm{~kg} \mathrm{~m}^{-3} ;+L 4 / 1$, max value $=18.21 \mathrm{~dB}, \mathrm{f}=4000 \mathrm{~Hz}, \mathrm{M}=800 \mathrm{~kg} \mathrm{~m}^{-3}$; the $2^{\text {nd }}$ spaces exhibited these values;

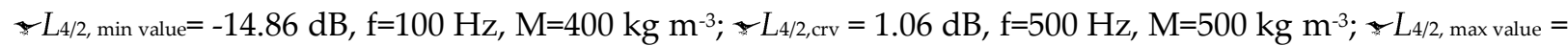
$23.21 \mathrm{~dB}, \mathrm{f}=4000 \mathrm{~Hz}, \mathrm{M}=800 \mathrm{~kg} \mathrm{~m}^{-3}$; while the $3^{\text {rd }}$ spaces indicated; $\because L 4 / 3$, min value $=-9.86 \mathrm{~dB}, \mathrm{f}=100 \mathrm{~Hz}, \mathrm{M}=400$ $\mathrm{kg} \mathrm{m}^{-3} ; \sim L 4 / 3, \mathrm{crv}=1.03 \mathrm{~dB}, \mathrm{f}=200 \mathrm{~Hz}, \mathrm{M}=700 \mathrm{~kg} \mathrm{~m}^{-3} ; \nleftarrow L 4 / 3$, max value $=28.21 \mathrm{~dB}, \mathrm{f}=4000 \mathrm{~Hz}, \mathrm{M}=800 \mathrm{~kg} \mathrm{~m}^{-3} ;$ as for the $4^{\text {th }}$ spaces, the values were; $\forall L 4 / 4$, min value $=-4.86 \mathrm{~dB}, \mathrm{f}=100 \mathrm{~Hz}, \mathrm{M}=400 \mathrm{~kg} \mathrm{~m}^{-3} ; \quad+L 4 / 4, \mathrm{crv}=0.00 \mathrm{~dB}, \mathrm{f}=100$ $\mathrm{Hz}, \mathrm{M}=700 \mathrm{~kg} \mathrm{~m}^{-3} ;+L 4 / 4$, max value $=33.21 \mathrm{~dB}, \mathrm{f}=4000 \mathrm{~Hz}, \mathrm{M}=800 \mathrm{~kg} \mathrm{~m}^{-3}$. The investigation found no irregularities in terms of sound levels for the $4^{\text {th }}$ climatic region between $5-11$; while the best case in these 
sections (5-11) occurred at $\mathrm{f}=4000 \mathrm{~Hz}$ and $\mathrm{M}=800 \mathrm{~kg} \mathrm{~m}^{-3}$. Here the values are; $-\mathrm{L} 4 / 5$, max value $=38.21 \mathrm{~dB}$,

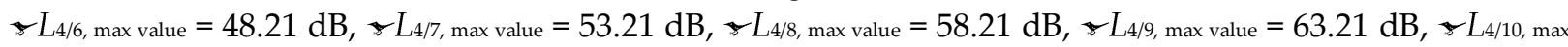
value $=68.21 \mathrm{~dB},-L 4 / 11$, max value $=78.21 \mathrm{~dB}$. Fig. 6 shows variation of $\mathrm{ANN}$ and actual data for the $4^{\text {th }}$ climatic region based on frequency and TS.

When the Tables 5-8 are evaluated for 1,2,3,4,5 spaces that need strong insulation in Table 3, it is found that the sound transmission losses are not sufficient. These insufficient values were particularly found at these frequencies: 100, 200, 500, $1000 \mathrm{~Hz}$. As for the sections 6-11, the single layer lightweight concrete wall cross sections as recommended by TSE 825 , were found to provide sufficient sound transmission loss. This is so because, these areas need no high level sound sensitvity and are generally public areas. With this study, it was found that it is necessary that apart from dimensioning the lightweight single concrete walls for thermal insulation under working frequencies of 100, 200, 500 and $1000 \mathrm{~Hz}$ with low densities, sound sensitive spaces described in 1-5 spaces should also be considered in terms of sound transmission losses. In addition, the buildings in the $1^{\text {st }}$ climatic region which need lower thermal insulation were also found to have lower inner sound insulation; and as the need for the thermal insulation increases in the $2^{\text {nd }}, 3^{\text {rd }}$, and $4^{\text {th }}$ climatic regions, the sound insulation increases too. It is therefore determined that thermal and sound transmissions go hand in hand.

Table 8. $-L$ for lightweight concrete wall in 4 th climatic region

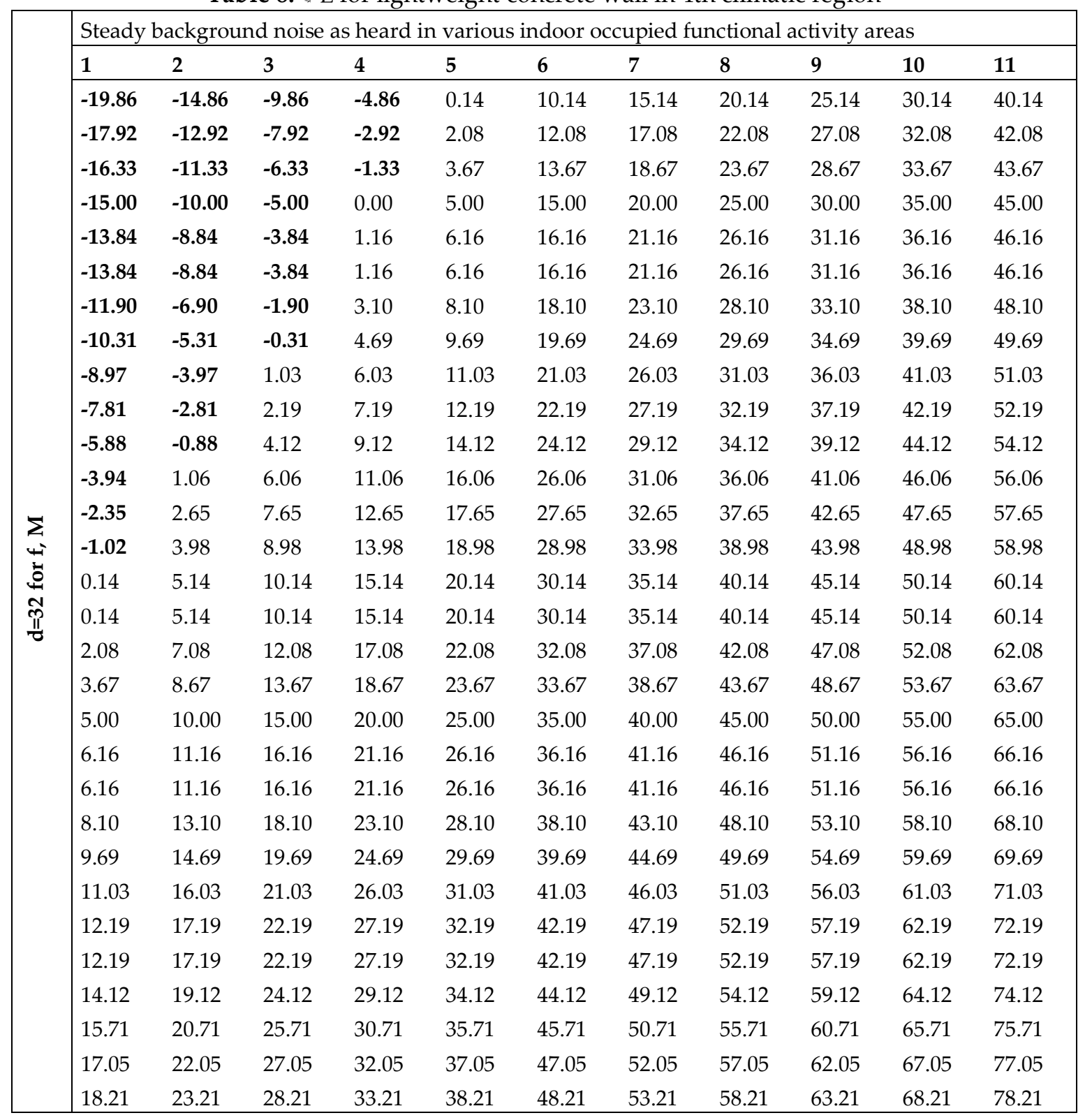


When the results of ANN modeling for the transmitted sound are evaluated together (Figure 3-6), it is found that the maximum sound transmission occurs on the $1^{\text {st }}$ climatic region, at a frequency of 100 $\mathrm{Hz}$, wall density of $400 \mathrm{kgm}^{-3}$ and sound level of $42.38 \mathrm{~dB}$ (training) while the minimum sound transmission takes space on the $4^{\text {th }}$ climatic region and at a frequency of $4000 \mathrm{~Hz}$, density of $800 \mathrm{kgm}^{-3}$ and sound level of $-1.76 \mathrm{~dB}$ (prediction). Some statistical methods are defined as follows: The error during the learning session is called the root-mean-square (RMS) value and is defined as follows (Sözen and Arcaklioglu, 2007):

$$
R M S=\left((1 / p) \sum_{j}\left|t_{j}-o_{j}\right|^{2}\right)^{1 / 2}
$$

In addition, absolute fraction of variance $\left(\mathrm{R}^{2}\right)$ and mean absolute percentage error (MAPE) are defined as follows, respectively (Sözen and Arcaklioglu, 2007):

$$
R^{2}=1-\left(\frac{\sum_{j}\left(t_{j}-o_{j}\right)^{2}}{\sum_{j}\left(o_{j}\right)^{2}}\right)
$$

where $\mathrm{t}$ is target value, o is output value, and $\mathrm{p}$ is pattern (Sözen and Arcaklioglu, 2007)

$$
M A P E=\frac{o-t}{o} \times 100
$$

The statistical values such as RMS, R², MAPE are given in Table 9. When Table 9 is studied, it is found that the ANN values cope well with the actual values.

Table 9. The statistical error values for TS

\begin{tabular}{|llll|}
\hline RMS & $\mathbf{R}^{2}(\mathbf{\%})$ & MAPE(\%) & ANN \\
\hline 0.89 & 99.49 & 2.56 & Training \\
0.15 & 99.51 & 1.11 & Test \\
\hline
\end{tabular}

\section{CONCLUSION}

In this study, analysis of sound transmission losses through lightweight concrete walls was conducted against the high way trafic noises. The walls are generally used for thermal insulation purposes in Turkey. Sound transmission was modeled using ANN.

The conclusions drawn in this paper are summarized as follows:

Sound transmission losses improve with higher frequencies, higher wall densities and increased wall cross sections.

$>$ Regardless of sufficient thermal insulation of single layered lightweight concrete walls as stipulated by the Turkey Institute of Standards (TSE 825), the wall cross sections were found to be insufficient in terms of sound transmission (Figures 5-8). 
> Beside thermal insulation of the single layered lightweight concrete walls' regulations, it was found with this study that, it is also necessary to analyze sound transmission lossess, after which the wall cross sections should be sized.

$>$ The ANN was trained and tested by means of toolbox of the MATLAB software on a personal computer.

> Input parameters $\mathrm{d}_{2}, \mathrm{f}, \mathrm{M}$ and output parameter TS were described.

$>$ In modeling the lightweight concrete walls for sound transmission against the highway noises, the back-propagation algorithm has been implemented to calculate errors and adjust weights of the hidden layer neurons. The sigmoid function was chosen as the transfer function. Number of neurons in the hidden layer and epoch numbers were tested for different values $(100,250,500$ and 1000 epoch). The model was tested on 2, 3, 4 and 5 neurons. A network of 2 neurons was chosen as it yielded the most appropriate results.

$>\mathrm{R}^{2}$ for training the TS is $99.49 \%$ and $\mathrm{R}^{2}$ for testing the TS is $99.51 \%$. The actual values and ANN results show that ANN can be successfully used for analyzing sound transmission through lightweight concrete walls against highway noises.

\section{REFERENCES}

Ballagh, K.O., "Accuracy of Prediction Methods for Sound Transmission Los, Inter-Noise 2004", The 33rd International Congress and Exposition on Noise Control Engineering, New Zealand, 2004.

Bao, C., Pan, J., 1997, "Experimental Study of Different Approaches for Active Control of Sound Transmission Through Double Walls", Journal of Acoustical Society of America, Vol. 102, pp. 1664-1670.

Beranek, L.L., Ver, I. L., 1992, Noise and Vibration Control Engineering Principles and Aplications. A WileyInterscience Publication, New York, p. 633.

Croome, D. J., 1992, Noise and the Design of Buildings and Services, Construction Press, New York, p. 31.

Jeona, J.Y., Ryu, J. K, Leea, P. J., 2010, “A Quantification Model of Overall Dissatisfaction with Indoor Noise Environment İn Residential Buildings", Applied Acoustics, Vol. 71, pp. 914-921. 3]

Julien, L., Noureddine, A., 2009, “Numerical and Experimental Investigation of the Effect of Structural Links on the Sound Transmission of a Lightweight Double Panel Structure", Journal of Sound and Vibration, Vol. 324, pp. 712-732.

Kalogirou, S.A., Bojic, M., 2000, "Artificial Neural Networks for the Prediction of The Energy Consumption of a Passive Solar Building", Energy, Vol. 25, pp. 479-491.

Kalogirou, S.A., 2000, "Applications of Artificial Neural-networks for Energy Systems", Applied Energy, Vol. 67, pp. 17-35.

Kalogirou, S.A., 2003, "Artificial Intelligence for the Modeling and Control of Combustion Processes: a Review", Progress in Energy and Combustion Science, Vol. 29, pp. 515-566.

Kocabas, F., Korkmaz, M., Sorgucu, U., Donmez, S., 2010, "Modeling Of Heating And Cooling Performance of Counter Flow Type Vortex Tube by Using Artificial Neural Network", International Journal of Refrigeration, Vol. 33, pp. 963-972 [17] Özer, M., 1979, Yapr Akustği ve Ses Yalıtım, Arpaz Publication, Istanbul, Turkey, pp.143.

Kumar, M.M., Stoll, N., Stoll, R., 2006, "An Energy-Gain Bounding Approach to Robust Fuzzy Identification", Automatica, Vol. 42, pp. 711-721.

Matsumoto, T., Uchida, M., Sugaya, H., Tachibana, H., 2006, “Development of Multiple Drywall with High Sound Insulation Performance", Applied Acoustics, Vol. 71, pp. 595-608.13]

Olanrewaju, O.A., Jimoh, A.A., Kholopane, P.A., 2012, “Integrated IDA-ANN-DEA for Assessment and Optimization of Energy Consumption in İndustrial Sectors", Energy, Vol. 46, pp. 629-635.

Oldhama, D.J, Mohsen, E.A., 2003, "A Model Investigation of the Acoustical Performance of Courtyard Houses with Respect to Noise from Road Traffic", Applied Acoustics, Vol. 12, pp. 215-230. 
Sözen, A., Arcaklioglu, E., 2007, "Exergy Analysis of an Ejector-Absorption Heat Transformer Using Artificial Neural Network Approach", Applied Thermal Engineering, Vol. 27, 481-491.

Safa, M., Samarasinghe, S., 2013, "Modelling Fuel Consumption in Wheat Production Using Artificial Neural Networks", Energy, Vol. 49, pp. 337-343.

Tosun, M., Dincer, K., 2011, "Modelling of a Thermal Insulation System Based on the Coldest Temperature Conditions by Using Artificial Neural Networks to Determine Performance of Building for Wall Types in Turkey, International Journal of Refrigeration, Vol. 34, pp. 362-373.

TS 825, Thermal Insulation Requirements for Buildings, Ankara, Turkey, 2008.

Vigran, T.E., 2009, "Predicting the Sound Reduction Index of Finite Size Specimen by a Simplified Spatial Windowing Technique", Journal of Sound and Vibration, Vol. 325, pp. 507-512.

Yang, J., Rivard, H., Zmeureanu, R., 2005, “On-line Building Energy Prediction Using Adaptive Artificial Neural Networks", Energy and Buildings, Vol. 37, pp. 1250-1259.

Wang, J., Lu, T.J, Woodhouse, J., Langley, R.S, Evans, J., 2005, "Sound Transmission Through Lightweight Double-Leaf Partitions: Theoretical Modelling", Journal of Sound and Vibration, Vol. 286, pp. 817-847.

WHO, http://www.euro.who.int/en/who-we-are/policy-documents (Accessed 05 May 2012).s

Zhang, C.L., 2005, "Generalized Correlation of Refrigerant Mass Flow Rate Through Adiabatic Capillary Tubes using Artificial Neural Network", International Journal of Refrigeration, Vol. 28, pp. 506514. 